\title{
IN MEMORIAM \\ HULDEBLYK AAN PROF C P T NAUDÉ \\ (17.08.1912 - 10.08.2001)
}

D M Kriel (Universiteit van Suid-Afrika, Emeritus)

Professor Naude is vanjaar op 10 Augustus oorlede - een week voordat hy sy negeen-tagtigste verjaarsdag sou gevier het.

Hy het 'n soliede loopbaan as klassikus gehad, eers as student en toe as dosent aan Wits; in 1955 promoveer hy onder prof Den Boer te Leiden met 'n proefskrif oor Ammianus Marcellinus in die Lig van die Antieke Geskiedskrywing wat - al was dit in Afrikaans geskryf - internasionaal hoog aangeskryf is (en nog word). In 1963, toe hy reeds vier jaar lank senior lektor in Klassieke Tale by Unisa was, is hy bevorder tot professor - die eerste volwaardige professor in Antieke Geskiedenis in Suid-Afrika. Hy het ook die KVSA baie, baie jare lank in verskeie hoedanighede gedien, en hy en prof Gonin was lank die twee steunpilare van Acta Classica.

Maar ons wat met hom saamgewerk het, ons wat die voorreg gehad het om sy vriende te wees, sal hom bowe-al onthou vir sy humanitas, sy beskeidenheid, sy bedagsaamheid, sy "wry sense of humour". Toe sy kollegas hom in 1993 vereer het met die bundel Charistion, het Ursula Vogel haar huldeblyk afgesluit met 'n aanhaling uit Chaucer wat net so oor Charl Naudé geskryf kon gewees het:

And though so much distinguished, he was wise

And in his bearing gentle as a maid.

He never yet a boorish thing had said

In all his life to any, come what might:

he was a true, a perfect knight.

Met reg het sy familie op die voorblad van die begrafnisprogram bygevoeg:

Sola morte dolorem attulit.

"Slegs deur sy dood het hy ooit leed veroorsaak." 